\title{
BAGAIMANA STRATEGI PENGEMBANGAN WAKAF TUNAI DI INDONESIA?
}

\author{
Aam S. Rusydiana \\ Program Studi Ekonomi Islam \\ SekolahTinggiEkonomilslam Tazkia \\ Email: aamsmart@gmail.com \\ Solihah S. Rahayu \\ Program Doktoral \\ UniversitasIslam NegeriSunanGunungDjati \\ Email: solihah.sr@gmail.com
}

\begin{abstract}
ARTICLE
ABSTRACT

HISTORY

Received:

This study attempts to identify the causes and dominant factors

10 November that are obstacles in the development of cash waqf in Indonesia, using the IFE EFE Matrix and SWOT methods, and the

2018

Accepted: solutions offered. Based on the results of IFE analysis, the highest ranking of strengths is the ability of cash waqf in 28 June 2019 expanding the base of waqf fund sources followed by ease and Online available: zero cost of funds. While the ranking of weaknesses is the lack 30 June 2019 of socialization to the community followed by the lack of professional Nazhir human resources. The results of EFE analysis

Keywords:

Cash Waqf, that the highest ranking of opportunities is the potential of unlimited cash waqf followed by the emergence of many sharia Indonesia, IFEEFE Matrix, Strategic Management financial institutions and Islamic economics study programs in universities. While the highest ranking of threats, namely the relatively weak political will of authorities, and followed by the majority of traditional Nazhirs. It is expected that there will be a joint commitment from various parties, both from policy makers and academics and practitioners to support and encourage efforts to develop the Islamic (social) finance industry, especially in this case the development of cash waqf in Indonesia.
\end{abstract}

\section{ABSTRAK}

Kata Kunci: Penelitian ini mencoba untuk mengidentifikasi penyebab serta WakafTunai, faktor-faktor yang dominan menjadi hambatan dalam Indonesia, Matriks IFAS pengembangan wakaf tunai di Indonesia, dengan pendekatan metode IFAS EFAS Matrix dan SWOT, berikutsolusi yang 
EFAS

ditawarkan. Berdasarkan hasil analisis IFE bahwa peringkat tertinggi dari kekuatanya itu kemampuan wakaf tunai dalam memperluas basis sumber dana wakaf diikuti dengan kemudahan dan zero cost of fund. Sedangkan peringkat kelemahan yaitu kurangnya sosialisasi kepada masyarakat diikuti dengan kekurangan SDM nazhir yang profesional. Adapun hasil analisis EFE bahwa peringkat tertinggi dari peluangya itu potensi wakaf tunai yang tidak terhingga diikuti dengan banyak munculnya lembaga keuangan syariah berikut prodi ekonomi syariah pada perguruan tinggi. Sedangkan peringkat tertinggi ancamanya itu relatif lemahnya political will pemegang otoritas diikuti dengan mayoritas nazhir yang masih tradisional. Diharapkan adanya komitmen bersama dari berbagai pihak baik dari pembuat kebijakan maupun akademisi dan praktisi dalam menunjang dan mendorong upaya pengembangan industri keuangan syariah khususnya dalam hal ini pengembangan wakaf tunai di Indonesia.

\section{PENDAHULUAN}

Industri keuangan syariah, menjadi objek studi yang selalu menarik diteliti. Terutama jika dikomparasi dengan kondisi industri keuangan konvensional yang telah lebih dahulu eksis. Misalnya, hasil penelitian yang dilakukan oleh Nurfalah etal (2018) yang menyatakan bahwa perbankan syariah relatif lebih stabil dibandingkan dengan perbankan konvensional dalam menghadapi shock baik dari internal maupun eksternal. Hal ini menjadi temuan menarik yang perlu dibuktikan melalui berbagai riset di masa mendatang.Selain industri keuangan seperti bank syariah, asuransi syariah, pegadaian syariah dan sebagainya, dalam keuangan Islam dikenal pula entitas keuangan sosial yang juga memiliki peran yang tidak kalah penting. Industri Islamic social finance tersebut antara lain adalah lembaga zakat, lembaga wakaf, baitul maal wat tamwiil dan sebagainya. Salah satu instrumen penting dan memiliki potensi yang sangat besar dari sisi sosial maupun finansial adalah wakaf uang. Secara umum, hampir di seluruh dunia perkembangan ekonomi dan keuangan Islam menunjukkan tren yang positif (Rusydiana etal, 2009), termasuk wakaf.

Wakaf uang merupakan inovasi baru dalam sistem keuangan Islam sektor voluntary disamping zakat, infaq, dan shadaqah. Instrumen ini tidak hanya memecah kebekuan makna institusi wakaf di berbagai negara muslim, tetapi juga merupakan peluang yang luar biasa bagi pengembangan ekonomi sosial umat secara keseluruhan. 
Menurut Devi (2015), wakaf uang juga memberikan kesempatan bagi masyarakat berbagai kalangan untuk berpartisipasi menunaikan wakaf uang sekalipun tidak dalam jumlah besar. Di Indonesia, wakaf uang mulai dikembangkan pada tahun 2001, tatkala para pakar ekonomi Islam melihat banyaknya aset wakaf di Indonesia tidak diberdayakan secara maksimal. Maka pada tahun 2002, Komisi Fatwa Majelis Ulama Indonesia (MUI) mengeluarkan fatwa tentang wakaf uang, yang berisi (1) Wakaf uang (cash waqf/waqf al-nuqud) adalah wakaf yang dilakukan seseorang, lembaga atau badan hukum dalam bentuk uang tunai, (2) Termasuk ke dalam pengertian uang adalah surat-surat berharga, (3) Wakaf uang termasuk jawaz (boleh), (4) Wakaf uang hanya boleh disalurkan dan digunakan untuk hal-hal yang dibolehkan syar'i, (5) Nilai pokok wakaf uang harus dijamin kelestariannya, tidak boleh dijual, dihibahkan dan atau diwariskan.

Indonesia sebagai negara mayoritas muslim tentu memiliki potensi wakaf uang yang sangat besar. Menurut Nasution (2012), potensi wakaf uang di Indonesia dengan jumlah umat muslim dermawan diperkirakan sebanyak 20 juta umat dan mewakafkan hartanya dalam bentuk wakaf uang dengan nominal Rp 1 juta per tahun, maka potensi wakaf yang terkumpul bisa mencapai Rp 20 Triliun. Namun, di samping potensi yang besar, tidak sedikit tantangan dan ancaman yang dihadapi dalam kerangka pengembangan instrumen keuangan sosial Islam ini. Salah satu diantaranya misal, belum detailnya data terkait wakaf secara umum demikian juga terkait wakaf tunai. Aspek tantangan yang dihadapi lainnya dalam pengembangan wakaf tunai di Indonesia, antara lain: Sistem, Peraturan, Produk, dan Teknologi informasi. Challenges berikutnya adalah: Kepercayaan, aspek Syariah dan terakhir namun tidak kalah penting adalah terkait Sumber daya manusia (Rusydiana, 2018). Oleh karena itu, berdasarkan latar belakang yang telah diungkapkan di atas, maka rumusan masalah yang diangkat dalam penelitian ini adalah: apa sajakah masalah-masalah yang dihadapi dalam kerangka pengembangan wakaf tunai di Indonesia? Apa saja solusi dan strategi yang harus diterapkan dalam kerangka strategis jangka panjang? Dengan pendekatan metode IFAS EFAS Matrix dan SWOT beberapa pertanyaan tersebut akan coba dijawab dan dicarikan solusinya.

\section{LANDASAN TEORI}

Pengertian wakaf dalam peristilahan syara', secara umum wakaf adalah sejenis pemberian yang pelaksanaannya dilakukan dengan jalan menahan (pemilikan) asal (tahsibul ashli), lalu menjadikan manfaatnya berlaku umum. Tahsibul ashli adalah menahan barang untuk diwakafkan agar tidak diwariskan, dijual, dihibahkan, digadaikan, disewakan, dan sejenisnya. Cara pemanfaatannya dengan menggunakan sesuai kehendak wakif/tanpa imbalan (Al-Arif, 2010).Adapun pengertian wakaf menurut UU No. 41 Tahun 2004 Tentang Wakaf Pasal 1 ayat (1) : Wakaf adalah perbuatan hukum wakif untuk memisahkan dan/atau menyerahkan sebagian harta benda miliknya untuk 
dimanfaatkan selamanya atau untuk jangka waktu tertentu sesuai dengan kepentingannya guna keperluan ibadah dan/atau kesejahteraan umum menurut syariah.

Majelis Ulama Indonesia (MUI) telah mendefinisikan wakaf uang dalam fatwanya tentang kebolehan wakaf pada 11 Mei 2002 yang menyatakan bahwa wakaf uang (cash waqf/waqf al nuqud) adalah wakaf yang dilakukan seseorang, kelompok orang, lembaga atau badan hukum dalam bentuk uang tunai, termasuk dalam pengertian ini adalah surat-surat berharga. Definisi ini kemudian diperkuat dengan lahirnya UU No. 41 Tahun 2004 dan PP No, 42 Tahun 2006 tentang wakaf yang menyatakan bahwa uang termasuk bagian dari benda wakaf. Dapat disimpulkan bahwa wakaf uang adalah aset berupa uang yang dimanfaatkan secara produktif pada sektor halal guna kemaslahatan umat Islam, khususnya mauquf 'alaih. Adapun zat pada wakaf uang tersebut tidak boleh berkurang atau hilang.Menurut Mu'alim (2014) dalam Haura, Baga, Tanjung (2016), terdapat beberapa ulama yang membolehkan wakaf uang, diantaranya :Imam al-Zuhri (w. $124 \mathrm{H}$ ) menjelaskan bahwa mewakafkan dinar hukumnya boleh, dengan cara menjadikan dinar tersebut sebagai modal usaha kemudian keuntungannya disalurkan pada mauquf 'alaih.Para ulama mutaqaddimin (klasik) dari kalangan madzhab Hanafi, membolehkan wakaf dinar dan dirham sebagai pengecualian, atas dasar Isthsan bi al-'Urf, berdasarkan atsar dari Abdullah bin Mas'ud r.a. "Apa yang dipandand baik oleh kaum muslimin maka dalam pandangan Allah adalah baik, dan apa yang dipandang buruk oleh kamu muslimin maka dalam pandangan Allah pun buruk".

Sebagian ulama madzhab al-Syafi'i. “Abu Tsaur meriwayatkan dari Iman al-Syafi'i tentang kebolehan wakaf dinar dan dirham (uang)". Mas'udi et al. (2016) melakukan analisis terhadap pengembangan wakaf tunai (Waqf al-Nuqud) di Indonesia. Penelitian menunjukan bahwa upaya pengembangan wakaf uang di Indonesia relatif masih baru jika dibandingkan dengan negara lain. Untuk itu diperlukan sinergi antara lembaga nazhir wakaf dengan lembaga amil zakat agar aktivitas wakaf uang lebih cepat berkembang, khususnya pada masa-masa awal pertumbuhannya. Diperlukan peran yang lebih besar dari Lembaga Keuangan Syariah Penerima Wakaf Uang agar sinergi antara nazhir wakaf dengan LKS PWU profesional lebih maksimal.Haura Arie et al. (2016) melakukan analisis pengelolaan wakaf uang pada Koperasi Jasa Keuangan Syariah (pendekatan Analytical Network Process). Hasil penelitian ini memaparkan proses Koperasi Jasa Keuangan Syariah (KJKS) sebagai nazhir wakaf uang, menganalisa prioritas faktor internal dan eksternal terkait. Prioritas faktor-faktor strategis dalam pengelolaan wakaf uang secara berurutan dari sisi internal adalah Akuntabilitas, Produk, dan SDM KJKS. Dari sisi eksternal adalah Regulasi, Masyarakat Umum, dan Demografi. Secara detail, prioritas utama adalah pada elemen Jumlah Asset dan Pedoman Prinsip Syariah. 
Nizar (2014) menganalisis faktor-faktor yang mempengaruhi persepsi wakif tentang wakaf uang menggunakan metode regresi logistik. Hasil analisis data menunjukan bahwa variabel pendidikan memiliki peluang yang lebih besar dan signifikan dalam menjelaskan persepsi wakif tentang wakaf uang. Hal ini karena tingkat pendidikan lebih tinggi mampu mengolah informasi yang diterima secara lebih baik dibandingkan tingkat pendidikan yang lebih rendah sehingga membentuk pemahaman yang lebih baik. Budiman (2011) mengungkapkan beberapa penyebab yang membuat wakaf tidak efektif. Di salah satu sisi, penyebabnya terkait dengan sumber daya manusia, khususnya pada sisi pengelola (nazhir), penyebab yang lain adalah lemahnya akuntabilitas dari institusi wakaf. Dengan menggunakan pendekatan doktrinal dan non-doktrinal penelitian inimenunjukkan bahwa di PKPU pengelola menerapkan prinsip transparansi dan akuntabilitas dalam mengelola wakaf di dalam lembaga itu. Prinsip akuntabilitas diimplementasikan dalam bentuk audit, baik internal maupun eksternal oleh akuntan publik. Penerapan prinsip akuntabilitas telah meningkatkan kepercayaan publik terhadap lembaga wakaf.

Furqon (2011) mengkaji praktek perwakafan uang pada lembaga keuangan syariah. (Bank Syariah Mandiri). Ada beberapa kesimpulan yang dapat ditarik dari kajian ini antara lain : penyebaran informasi wakaf uang masih relatif terbatas dibandingkan dengan kekayaan media dan pengalaman yang dimiliki oleh bank. Untuk meningkakan pemberdayaan wakaf uang tunai ada beberapa rekomendasi yang perlu dilakukan, yaitu Sosialisasi wakaf uang menjadi kewajiban semua pihak. Pemerintah harus memberikan perhatian yang besar terhadap sosialisasi wakaf uang dengan mengalokasikan anggaran yang cukup untuk sosialisasi dan penggalangan wakaf uang. Pihak bank perlu lebih mengintensifkan sosialisasi wakaf uang dengan memanfaatkan layanan promosi produk yang dimilikinya; BWI perlu menyiapkan standar nazhir wakaf uang profesional dan memberikan pelatihan-pelatihan nazhir wakaf professional sehingga wakaf uang dapat berjalan sesuai dengan ketentuan.

Hasbullah (2012) melakukan penelitian mengenai Dinamika Pengelolaan Wakaf Uang dengan melakukan Studi tentang Perilaku Pengelolaan Wakaf Uang Pasca Pemberlakuan UU No. 41 Tahun 2004 tentang Wakaf. Hasil penelitian menunjukan bahwa regulasi wakaf uang kurang mendukung terwujudnya wakaf uang sebagai alat pemberdayaan dan kesejajaran ekonomi di masyarakat. Skema pengelolaaan wakaf uang perlu disempurnakan dengan menjadikan LKS sebagai nazhir dan menjadikan dana wakaf uang sebagai modal bisnis sosial integratif. Wakaf tunai untuk pembangunan sarana ekonomi produktif dan sosial yang berkembang di masyarakat perlu diakomodasi sebagai model wakaf dengan nazhir selain LKS. Penelitian lain terkait wakaf dan wakaf tunai telah dilakukan oleh Alias etal (2015), Harun et.al (2016), Aziz et.al (2014) 
Rusydiana \& Devi (2018), Rusydiana \& Devi (2017) dan Pitchay et.al (2014). Riset yang dilakukan oleh Rusydiana dan Alparisi (2016) menunjukkan bahwa riset-riset wakaf masih didominasi oleh diskusi terkait non-wakaf tunai (62\%) dibanding riset tentang wakaf tunai (38\%). Hal ini memberikan pandangan umum bagi para peneliti untuk memproduksi riset yang lebih baik terkait wakaf tunai. Sebagai tambahan, perbandingan riset wakaf dengan metode kuantitatif masih lebih sedikit dibandingkan dengan riset dengan pendekatan kualitatif.

\section{METODE PENELITIAN}

Tahapan penelitian diawali dari survey pendahuluan dan studi literature, identifikasi dan perumusan masalah, penentuan metode, penyusunan kuesioner, pengumpulan data, analisis data dan pengolahan hasil, analisis SWOT, serta penyusunan kesimpulan dan saran. Identifikasi dan perumusan masalah digunakan peneliti untuk memudahkan dalam menentukan arah penyelesaian masalah. Responden yang terdapat pada penelitian adalah pihak yang berkompeten serta mengetahui secara keseluruhan kondisi wakaf tunai di Indonesia baik secara internal maupun eksternal. Jumlah responden adalah 9 orang terdiri dari akademisi, praktisi dan regulator. Expert judgement (penilaian dari ahli) juga digunakan untuk mengetahui bagaimana probabilitas dari akibat yang akan muncul sebab adanya suatu kejadian. Metode ini memberikan kepercayaan kepada ahli untuk mengetahui akibat yang akan terjadi (Harinaldi, 2005).

Kuesioner kemudian disusun setelah dilakukan penentuan sampel responden. Analisis data terdiri dari beberapa tahapan diantaranya adalah analisis matriks Internal Factor Evaluation (IFE) dan External Factor Evaluation (EFE), analisis matriks Internal Eksternal (IE), dan terakhir analisis matriks SWOT. Analisis lingkungan internal dan eksternal wakaf tunai dilakukan dengan pemberian bobot tingkat kepentingan terhadap faktor internal dan eksternal yang telah disusun, kemudian dilakukan penilaian rating terhadap faktor internal eksternal tersebut. Total dari keseluruhan bobot faktor internal adalah 1, total bobot faktor eksternal adalah 1 . Total skor pada matriks IFE dan EFE digunakan untuk menentukan posisi dan kondisi wakaf tunai saat ini, dan strategi apa yang dapat diterapkan. Parameter yang digunakan dalam matriks IE meliputi parameter kekuatan internal dan pengaruh eksternal yang dihadapi. Tujuan penggunaan model ini adalah untuk memperoleh strategi di tingkat makro yang lebih detail.

Tahap selanjutnya setelah penentuan posisi pengembangan wakaf tunai menggunakan matriks IE adalah penyusunan matriks SWOT. Matriks SWOT disusun berdasarkan faktor kekuatan, kelemahan, peluang dan ancaman yang diperoleh dari hasil analisis dan diskusi dengan pakar. Penyusunan matriks SWOT bertujuan untuk 
menyusun alternative strategi yang dapat digunakan untuk pengembangan wakaf tunai di Indonesia. Jannah et al. (2013) mengemukakan bahwa, alat yang dipakai untuk menyusun faktor-faktor strategis adalah matriks SWOT yang dapat menggambarkan secara jelas bagaimana peluang dan ancaman eksternal yang dihadapi instrumen wakaf tunaidapatdiselesaikandengankekuatandankelemahan yang dimilikinya.Aplikasi metode IFAS-EFAS dalam riset ekonomi dan keuangan Islam misalnya dapat dilihat dalam penelitian yang dilakukan oleh Widiastuti et.al (2017) dan Rusydiana \& Firmansyah (2018) tentang strategi pengembangan lembaga keuangan mikro syariah di Indonesia. Secara umum riset dengan menggunakan IFAS-EFAS ini banyak digunakan dalam kerangka riset manajemen strategis dan pengambilan keputusan.

\section{HASIL DAN PEMBAHASAN}

Dalam penelitian ini identifikasi masalah internal dan eksternal diperlukan untuk mengetahui kekuatan dan kelemahan, kesempatan dan ancaman dalam rangka pengembangan wakaf tunai di Indonesia.Dalam penelitian ini, faktor internal dan eksternal dilihat dari sudut wakaf tunai itu sendiri sebagai objek yang diteliti untuk kemudian dianalisis. Adapun faktor internal meliputi kekuatan dan kelemahan yang dimiliki oleh instrumen wakaf tunai serta faktor eksternal meliputi peluang dan ancaman luar yang akan dihadapi. Perumusan strategi akan memperhitungkan kedua faktor tersebut untuk kemudian dihasilkan sebuah strategi yang paling sesuai dalam rangka mengembangkan wakaf tunai di Indonesia.Analisis faktor internal (kekuatan dan kelemahan) dan eksternal (peluang dan ancaman) diperoleh melalui kajian pustaka dan indepth interview terhadap para responden pakar yang memahami permasalahan pengembangan wakaf tunai di Indonesia. Sehingga dengan hal tersebut akan mampu dengan cepat dan tepat mengidentifikasi faktor-faktor strategis.

\section{Faktor Internal}

Faktor-faktor internal yang berpengaruh terhadap pengembangan wakaf tunai di Indonesia terdiri dari kekuatan dan kelemahan. Faktor yang menjadi kekuatan diantaranya yaitu: 1) Instrumen pengelolaan yang variatif, 2) Adanya fatwa MUI dan UU wakaf tunai, 3) Kemudahan berwakaf tunai dan zero cost of fund, 4) Memperluas basis sumber dana wakaf, dan 5) Konsep fikih wakaf yang fleksibel, dinamis dan terbuka. Sedangkan faktor yang menjadi kelemahan diantaranya yaitu: 1) Kurangnya sosialisasi tentang wakaf tunai kepada masyarakat umum, 2) Kekurangan SDM dan nazhir yang profesional, 3) Aset wakaf strategis dan potensial belum teridentifikasi dan tersertifikasi dengan baik, 4) Jaringan bisnis yang belum kuat, serta 5) Tingkat kepatuhan sebagian lembaga wakaf yang masih lemah. 
Dari sisi instrumen investasi yang variatif, wakaf tunai memiliki instrumen mobilisasi dana yang bervariasi antara lain sertifikat wakaf tunai, wakaf investasi, wakaf saham, "awqaf properties investment fund" serta instrumen yang lain. Fatwa MUI dan UU tahun 2004 no 41 pun menjadi faktor kekuatan yang mendasari legalitas wakaf tunai di Indonesia. Keunggulan lainnya, wakaf tunai saat ini dapat dengan mudah dilakukan meskipun hanya dengan dana yang tidak besar dan bahkan dengan 'mencicil'. Kelebihan wakaf tunai yang lainnya adalah mampu memperluas basis sumber dana wakaf secara signifikan karena nominal wakaf tunai jauh lebih rendah dan bervariasi dibandingkan wakaf aset fisik misalnya tanah dan gedung. Terakhir, wakaf tunai memiliki konsep fikih yang cukup fleksibel, dinamis dan terbuka, sehingga mempermudah dari sisi inovasi dan pengembangannya. Selain kekuatan di atas, ada beberapa kelemahan wakaf tunai. Belum banyaknya masyarakat luas yang mengetahui, mengakibatkan konsep wakaf tunai harus lebih giat disosialisasikan. Sumber daya insani atau nazhir yang akan mengelola wakaf tunai pun tidak boleh asal-asalan karena menyangkut pengelolaan dana amanah umat. Selain itu, banyak aset wakaf yang potensial di beberapa daerah belum teridentifikasi dan tersertifikasi dengan baik. Data dari sistem informasi wakaf Kementerian Agama RI menyebutkan bahwa baru sekitar $63 \%$ tanah wakaf yang telah bersertifikasi. Kelemahan lainnya adalah bahwa jaringan bisnis dan investasi dalam pengembangan wakaf tunai belum kuat. Dan terakhir terkait kepatuhan sebagian lembaga wakaf yang masih lemah, terutama terkait kelembagaan dan manajemen investasi wakaf tunai.

\section{Faktor Eksternal}

Faktor-faktor eksternal yang berpengaruh terhadap pengembangan wakaf tunai di Indonesia terdiri dari kesempatan dan ancaman. Faktor yang menjadi kesempatan diantaranya yaitu: 1) Mayoritas penduduk Indonesia yang beragama Islam, 2) Dukungan dari pemerintah dan pemda, 3) Potensi wakaf tunai yang tak terhingga, 4) Minat masyarakat terhadap ekonomi syariah semakin tumbuh, dan 5) Banyak munculnya lembaga keuangan syariah dan program studi terkait ekonomi Islam di perguruan tinggi negeri dan swasta. Sementara itu, faktor-faktor yang menjadi ancaman yaitu: 1) Kondisi ekonomi yang tidak menentu, 2) Mayoritas nazhir yang masih tradisional, 3) Kurangnya pemahaman masyarakat terhadap wakaf tunai, 4) Lemahnya political will pemegang otoritas, dan 5) Belum sempurnanya UU wakaf yang ada.

Seperti diketahui, Indonesia adalah negara muslim terbesar di dunia dengan mayoritas penduduk beragama Islam. Hal ini menjadi kesempatan yang cukup besar bagi pengembangan wakaf tunai ke depan. Dukungan dari beberapa pemerintah daerah juga cukup menjadi peluang yang baik bagi wakaf tunai. Selain itu, potensi wakaf tunai yang 
'unlimited', menjadi peluang tersendiri yang perlu dioptimalkan. Saat ini masyarakat sedang geliat terhadap transaksi yang berbasis syariah sehingga keberadaan wakaf tunai diharapkan menjadi salah satu instrumen yang dapat dikembangan. Terakhir namun tidak kalah penting adalah banyak bermunculannya lembaga keuangan dan ekonomi syariah (LKES) serta program studi terkait ekonomi Islam dan turunannya di perguruan tinggi, baik negeri maupun swasta di Indonesia. Semua ini diharapkan menjadi peluang yang mampu dimanfaatkan menjadi keunggulan wakaf tunai di Indonesia.Selain peluang dan kesempatan di atas, ada beberapa ancaman (threats) yang dihadapi dalam kerangka pengambangan wakaf tunai di Indonesia. Pengaruhkrisisekonomipolitikdalamnegeri adalah salah satunya.Kebanyakannadzirwakaf yang masihtradisional dan kurang inovatif juga menjadi tantangan selanjutnya. Selain itu, tantangan lain adalah kebekuan umat Islam terhadap paham wakaf, seperti keyakinan sebagian umat Islam bahwa harta wakaf tidak boleh ditukar dengan alasan apapun, kebanyakan masyarakat mempercayakan harta wakafnya kepada seseorang yang dianggap tokoh dalam lingkungannya dan lain sebagainya. Terakhir adalah lemahnya political will otoritas dan belum sempurnanya regulasi terkait UU wakaf tunai menjadi tantangan terakhir yang perlu dijawab.

\section{Evaluasi Faktor Strategis}

Evaluasi faktor strategis terdiri dari Internal Factor Evaluation (IFE) dan External Factor Evaluation (EFE), yaitu dengan cara memberikan nilai bobot dan peringkat pada masing-masing faktor internal (kekuatan dan kelemahan) dan faktor eksternal (peluang dan ancaman). Hasil dari evaluasi tersebut adalah nilai yang diperoleh mempunyai derajat kepentingan relatif lebih tinggi dibandingkan faktor-faktor lainnya.

\section{Evaluasi Faktor Internal}

Yaitu pemberian bobot dan peringkat yang dilakukan oleh para responden terhadap masing-masing faktor kekuatan dan kelemahan. Hasil evaluasi faktor internal dapat dilihat pada tabel 4.1. Dari tabel tersebut dapat kita lihat bahwa faktor internal yang mempunyai derajat kepentingan paling tinggi yaitu memperluas basis sumber dana wakaf dan kemudahan \& zero cost of fund masing-masing mempunyai bobot rata-rata sebesar 0,152 dan 0,144. Kemudian diikuti dengan faktor konsep fikih wakaf yang fleksibel dan dinamis dengan bobot rata-rata sebesar 0,102 dan faktor instrumen pengelolaan yang variatif dengan bobot 0,094. Adanya fatwa MUI dan UU wakaf tunai merupakan faktor yang mempunyai derajat kepentingan terendah dari sisi kekuatan wakaf tunai dengan bobot rata-rata sebesar 0,085 .

Sedangkan faktor kelemahan yang mempunyai derajat kepentingan dalam pengembangan wakaf tunai paling tinggi yaitu kurangnya sosialisasi ke masyarakat 
dengan bobot rata-rata sebesar 0,127, yang diikuti dengan kekurangan nazhir yang profesional yaitu bobot rata-rata sebesar 0,110 . Sedangkan jaringan bisnis yang belum kuat menjadi faktor yang melemahkan pengembangan wakaf tunai dengan bobot ratarata sebesar 0,102 dan tingkat kepatuhan masih lemah dengan bobot 0,085. Adapun masalah belum teridentifikasi \& tersertifikasinya aset wakaf strategis menjadi faktor yang paling rendah dari sisi kelemahan wakaf tunai dengan bobot rata-rata 0,084.

Hasil analisis IFE juga menunjukkan bahwa perluasan basis sumber dana wakaf mempunyai peringkat tertinggi yaitu sebesar 4,5 yang artinya mempunyai pengaruh yang paling kuat dari sisi internal dalam rangka pengembangan wakaf tunai. Sedangkan peringkat kedua yaitu bahwa wakaf tunai memiliki instrumen pengelolaan yang variatif dengan nilai sebesar 2,8 yang artinya mempunyai pengaruh yang kuat. Selanjutnya peringkat ketiga dan selanjutnya yaitu adanya fatwa MUI dan UU wakaf tunai, kemudahan serta konsep fikih yang fleksibel sama-sama memiliki rating 2,0 yang artinya ketiga faktor ini diberi nilai paling rendah oleh para responden dari perspektif kekuatan.Selanjutnya diketahui juga dari sisi kelemahan bahwa kurangnya sosialisasi kepada masyarakat mempunyai peringkat tertinggi yaitu sebesar 3,8 yang artinya faktor ini mempunyai pengaruh yang paling besar dalam melemahkan perkembangan wakaf tunai. Kemudian peringkat kedua yaitu kurangnya SDM nazhir profesional dan tingkat kepatuhan lembaga wakaf yaitu sebesar 3,3 yang artinya mempunyai pengaruh yang cukup besar. Sedangkan faktor jaringan bisnis yang belum begitu kuat mempunyai nilai rating sebesar 3,0 serta belum tersertifikasinya aset-aset wakaf strategis adalah peringkat selanjutnya yaitu sebesar 2,3 yang artinya faktor ini diberi nilai paling rendah oleh para responden dari perspektif kelemahan wakaf tunai.

\section{EvaluasiFaktorEksternal}

Yaitu pemberian bobot dan peringkat yang dilakukan oleh para responden terhadap masing-masing faktor peluang dan ancaman. Hasil evaluasi faktor eksternal dapat dilihat pada tabel 4.1. Dari tabel tersebut dapat kita lihat bahwa faktor eksternal peluang yang mempunyai derajat kepentingan paling tinggi yaitu potensi wakaf tunai yang tidak terhingga mempunyai bobot rata-rata sebesar 0,139. Kemudian diikuti dengan faktor bermunculannya LKES dan prodi ekonomi Islam pada perguruan tinggi serta faktor mayoritas penduduk muslim masing-masing mempunyai bobot rata-rata sebesar 0,113 dan 0,098. Sedangkan faktor dukungan dari pemerintah dan minat masyarakat terhadap ekonomi syariah mempunyai bobot sebesar 0,090 dan 0,089.Sedangkan faktor ancaman yang mempunyai derajat kepentingan paling tinggi yaitu lemahnya political will pemegang otoritas dengan bobot rata-rata sebesar 0,146 yang diikuti dengan faktor mayoritas nazhir yang masih tradisional dengan rata-rata sebesar 0,122 dan faktor 
kurangnya pemahaman masyarakat terhadap wakaf tunai sebesar 0,113. Terakhir adalah faktor kondisi ekonomi yang tidak pasti dan belum sempurnanya UU wakaf yang ada masing-masing mempunyai rata-rata bobot sebesar 0,090.

Hasil analisis EFE menunjukkan bahwa dari sisi peluang, faktor potensi wakaf tunai yang 'unlimited' mempunyai peringkat tertinggi yaitu sebesar 4,3 yang artinya mempunyai pengaruh yang paling besar sebagai peluang dalam mengembangkan wakaf tunai. Kemudian peringkat kedua dan ketiga yaitu faktor maraknya LKES dan prodi ekonomi Islam pada perguruan tinggi serta faktor mayoritas penduduk muslim masingmasing sebesar 3,8 dan 2,8. Sedangkan peringkat keempat yaitu dukungan dari pemerintah dengan rating sebesar 2,5 dan selanjutnya minat masyarakat terhadap ekonomi syariah sebesar 1,8 yang maknanya faktor ini diberi nilai paling rendah oleh para responden dari perspektif peluang.Dari sisi ancaman, diketahui bahwa lemahnya political will dari pemegang otoritas mempunyai peringkat paling tinggi yaitu sebesar 4,5 yang artinya mempunyai faktor yang paling tinggi dalam mengancam perkembangan wakaf tunai. Kemudian peringkat kedua yaitu mayoritas nazhir yang masih tradisional dengan skor sebesar 3,8 sedangkan kurangnya pemahaman masyarakat terhadap wakaf tunai mempunyai rating skor sebesar 3,5. Yang terakhir adalah kondisi ekonomi yang fluktuatif dan belum sempurnanya UU wakaf yang ada dengan rating sebesar 2,5 dan 1,8 yang artinya faktor ini diberi nilai paling rendah oleh para responden dari perspektif ancaman. Berikut adalah hasil lengkap pengukuran bobot dan rating dari setiap elemen dalam IFE-EFE.

Tabel 1

Penilaian IFE - EFE

\section{FAKTOR STRATEGIS INTERNAL (IFE)}

BOBOT RATE BOBOT*RATE

1.605

\begin{tabular}{lccc}
\hline STRENGTHS & & & $\mathbf{1 . 6 0 5}$ \\
\hline 1) Instrumen pengelolaan yang variatif & 0.094 & 2.8 & 0.258 \\
\hline 2) Adanya fatwa MUI dan UU wakaf tunai & 0.085 & 2.0 & 0.171 \\
\hline 3) Kemudahan dan zero cost of fund & 0.144 & 2.0 & 0.288 \\
\hline 4) Memperluas basis sumber dana wakaf & 0.152 & 4.5 & 0.685 \\
\hline 5) Konsep fikih wakaf yang fleksibel, dinamis \& terbuka & 0.102 & 2.0 & 0.204 \\
\hline WEAKNESS & & & $\mathbf{1}$ \\
\hline 1) Kurangnya sosialisasi ke masyarakat & 0.127 & 3.8 & 0.476 \\
\hline 2) Kekurangan SDM/nazhir yang profesional & 0.110 & 3.3 & 0.357 \\
\hline
\end{tabular}


Bagaimana Strategi Pengembangan Wakaf Tunai Di Indonesia?

3) Aset wakaf strategis dan potensial belum

teridentifikasi dan tersertifikasi dengan baik

$0.084 \quad 2.3 \quad 0.190$

4) Jaringan bisnis yang belum kuat

$0.102 \quad 3.0 \quad 0.306$

5) Tingkat kepatuhan lembaga wakaf thd aturan

$\begin{array}{llll}\text { perwakafan (ex: kelembagaan \& manajemen investasi) } & 0.085 & 3.3 & 0.278\end{array}$ masih lemah

\begin{tabular}{llll}
\hline TOTAL & 1.085 & \multirow{2}{*}{3.211} \\
\hline FAKTOR STRATEGIS EKSTERNAL (EFE) & Mean & Mean \\
\hline OPPORTUNITIES & & & $\mathbf{1 . 6 6 5}$ \\
\hline 1) Mayoritas penduduk muslim & 0.098 & 2.8 & 0.269 \\
\hline 2) Dukungan dari pemerintah dan pemda & 0.090 & 2.5 & 0.224 \\
\hline 3) Potensi wakaf tunai yang tak terhingga & 0.139 & 4.3 & 0.590 \\
\hline 4) Minat mayarakat thd ekonomi syariah makin tumbuh & 0.089 & 1.8 & 0.157 \\
\hline 5) Banyak bermunculannya LKES \& Prodi El di PTN/PTS & 0.113 & 3.8 & 0.425
\end{tabular}

\section{THREATS}

1.892

\begin{tabular}{lccc}
\hline 1) Kondisi ekonomi yang tidak pasti & 0.090 & 2.5 & 0.224 \\
\hline 2) Mayoritas nazhir yang masih tradisional & 0.122 & 3.8 & 0.457 \\
\hline $\begin{array}{l}\text { 3) Kurangnya pemahaman masyarakat terhadap wakaf } \\
\text { tunai }\end{array}$ & 0.113 & 3.5 & 0.397 \\
\hline 4) Lemahnya political will pemegang otoritas & 0.146 & 4.5 & 0.657 \\
\hline $\begin{array}{l}\text { 5) Belum sempurnanya UU wakaf yang ada (No.41, } \\
\text { 2004) }\end{array}$ & 0.090 & \multirow{2}{*}{1.8} & 0.157 \\
\hline TOTAL & & & \\
\hline
\end{tabular}

Sumber: Hasil perhitungan penulis

Hasil kuadran IFE-EFE digunakanuntuk menentukan penilaian posisi objek wakaf tunai di Indonesia. Penilaian hasil evaluasi faktor internal (IFE) adalah sebesar 3,211 dan faktor eksternal adalah sebesar 3,557. Nilai ini berada pada kuadran I berwarna hijau yaitu "tumbuh dan kembangkan". Keberadaan wakaf tunai pada fase ini menunjukkan bahwa pengembangan wakaf tunai di Indonesia sedang mengalami tahap pertumbuhan dan harus dikembangkan karena mempunyai potensi yang sangat besar untuk 
kemaslahatan publik. Keberadaan faktor-faktor internal dan eksternal pada dasarnya menjadi dukungan yang sangat besar bagi wakaf tunai.

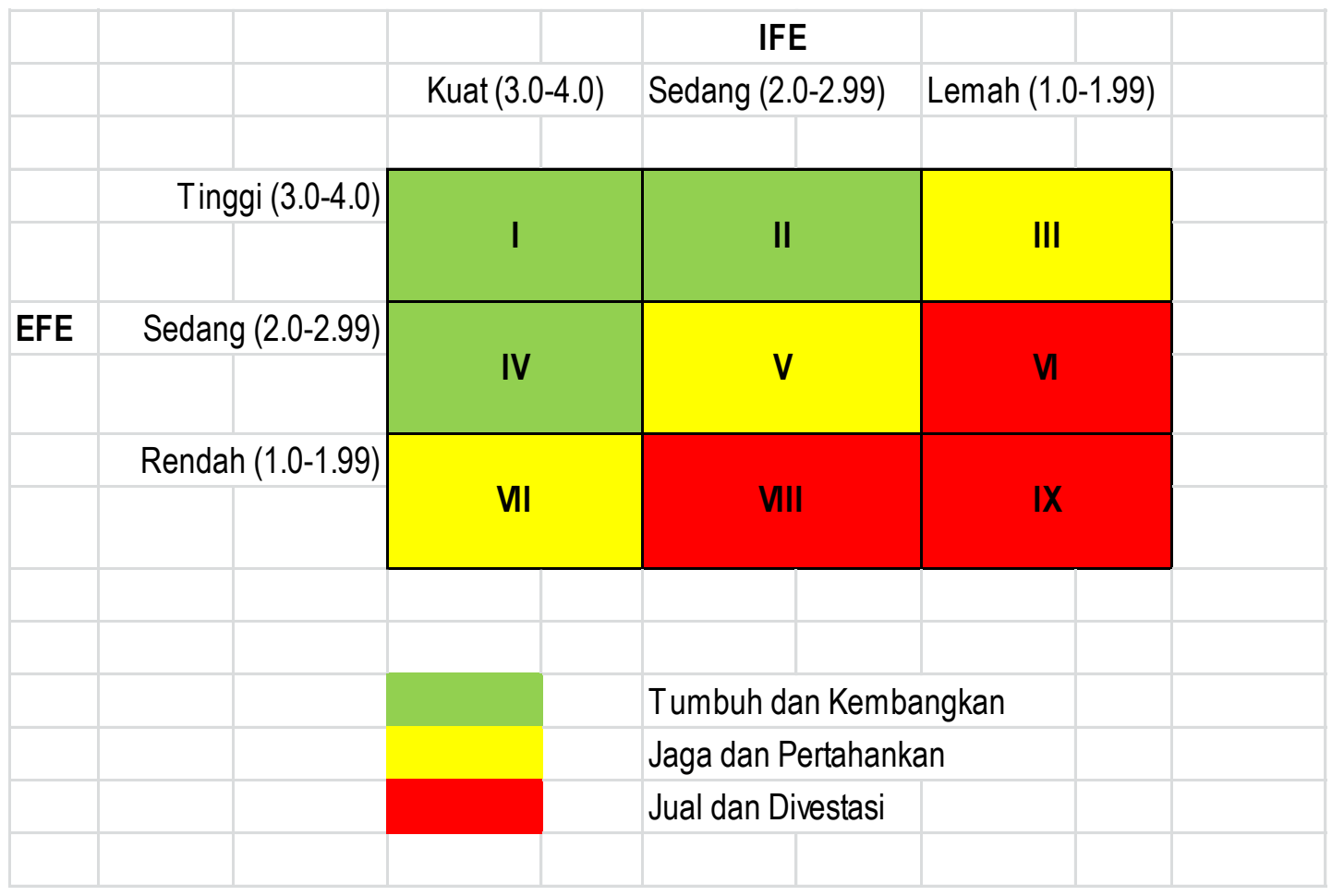

Sumber: Penulis, diolah

Gambar 1

Kuadran Matriks IFE - EFE

Masing-masing komponen SWOT pada kuadran IFE-EFE diberikan bobot dan rating. Bobot diperoleh dari nilai rotasi faktor yang dikalikan dengan nilai varian (eigenvalue). Sedangkan rating diperoleh dari hasil penilaian terhadap variabel-variabel yang diuji. Hasil pembobotan dan penilaian selanjutnya dijumlahkan untuk masingmasing komponen SWOT kemudian dicari selisih antara komponen internal (S dan W), dan selisih antara komponen eksternal (O dan T). Selisih komponen internal kemudian menjadi nilai sumbu x (nilai=0,44), dan hasil selisih komponen eksternal selanjutnya menjadi nilai sumbu y (nilai=0,35), sehingga pada kuadran IFE-EFE didapatkan posisi Survival pada kuadran IIIB seperti diperlihatkan oleh tabel 2.

Berdasarkan tabel2 dapat diketahui bahwa wakaf tunai di Indonesia berada pada Kuadran IIIB dengan strategi Survival Geurilla (Guerilla survival strategy). Pada kuadran tersebut, keberadaan wakaf tunai menunjukkan mempunyai kekuatan yang lebih kecil atau berimbang dalam lingkungan eksternal, namun bahayanya adalah ancaman yang dihadapi ternyata lebih besar dari kekuatan yang dimiliki. Oleh karena itu wakaf tunai 
harus lebih disosialisasikan secara lebih masif dan terstruktur agar lebih memberikan pemahaman yang komprehensif terhadap seluruh kalangan dan publik secara umum, dalam kerangka kemaslahatan yang lebih besar dan luas.

Tabel 2

KuadranStrategiWakaf Tunai

\begin{tabular}{llll}
\multicolumn{1}{c}{$\begin{array}{c}\text { Teknis } \\
\text { Strategis }\end{array}$} & Skor & Kuadran & Pilihan Strategi \\
\hline Growth & $\mathrm{S}>\mathrm{O}$ & I A & Rapid Growth \\
\hline Survival & $\mathrm{S}<\mathrm{O}>\mathrm{T}$ & I B & Stable Growth \\
\hline & $\mathrm{W}<\mathrm{T}$ & III B & Turn Around \\
\hline Diversification & $\mathrm{S}>\mathrm{T}$ & IV B & Guerilla \\
\hline & $\mathrm{S}<\mathrm{T}$ & IV A & Conglomerate \\
\hline Stability & $\mathrm{O}>\mathrm{W}$ & II A & $\begin{array}{l}\text { Aggressive } \\
\text { Maintenance }\end{array}$ \\
\hline & & & Selective \\
& $\mathrm{O}<\mathrm{W}$ & II B & Maintenance
\end{tabular}

Sumber: Penulis, diolah

Alternatif strategi yang dapat dijadikan masukan adalah strategi S-T karena strategi S-T merupakan strategi untuk memanfaatkan kekuatan/keunggulan yang dimiliki untuk menghindari atau meminimalisir dampak dari ancaman yang sangat besar. Adapun alternatif strategi S-T dapat dilihat pada hasil analisis strategi SWOT. Perumusan alternatif strategi pengembangan wakaf tunai di Indonesia dengan analisis SWOT merupakan gabungan antara faktor internal (kekuatan dan kelemahan) dengan faktor eksternal (tantangan dan ancaman) yang terdiri dari:

1) Gabungan faktor kekuatan dan peluang

2) Gabungan faktor kelemahan dan peluang

3) Gabungan faktor kekuatan dan ancaman

4) Gabungan faktor kelemahan dan ancaman.

Berdasarkan faktor kekuatan, kelemahan, peluang dan ancaman yang telah teridentifikasi, maka melalui analisis SWOT dapat dirumuskan 7 alternatif strategi 
pengembangan wakaf tunai di Indonesia yaitu: (a) transparansi dan akuntabilitas lembaga wakaf, (b) peningkatan kualitas nazhir pengelola wakaf tunai, (c) strategi pemasaran yang inovatif dari lembaga wakaf dan (e) dukungan regulasi wakaf. Strategi prioritas selanjutnya adalah: (d) pengembangan institusi pendidikan wakaf, dan (g) teknologi dan komputerisasi manajemen wakaf. Yang terakhir namun tidak kalah penting adalah (f) Update dan validasi terkait data wakaf dan wakaf tunai.

Relevan dengan hasil riset yang dilakukan oleh Ihsan etal (2017), Hasan \& Siraj (2017) dan Masruki \& Shafii (2013), hasil elaborasi strategi pengembangan wakaf tunai berdasarkan hasil depth interview dengan pakar menunjukkan bahwa hal penting yang mempengaruhi pemilihan lembaga wakaf di Indonesia adalah faktor transparansi keuangan (akuntabilitas). Hal ini berimplikasi bahwa lembaga wakaf harus senantiasa amanah dan bertanggung jawab penuh dalam mengelola dana dan objek wakaf. Pada sisi ini, konsep mengenai akuntabilitas, transparansi dan aksesibilitas menempati kriteria yang sangat penting terkait dengan pertanggungjawaban lembaga wakaf dalam menyajikan, melaporkan dan mengungkap segala aktifitas kegiatan serta sejauh mana laporan keuangan memuat semua informasi yang relevan yang dibutuhkan oleh para wakif dan seberapa mudah informasi tersebut diakses oleh publik.

\section{SIMPULAN}

Dalam rangka memperoleh strategi pengembangan wakaf tunai di Indonesia, maka harus diperhatikan terlebih dahulu dua faktor penting, yaitu faktor internal (sebagai faktor kekuatan dan kelemahan) dan faktor eksternal (sebagai faktor peluang dan ancaman). Hasil evaluasi faktor internal menunjukkan bahwa kekuatan tertinggi wakaf tunai yaitu kemampuannya memperluas basis sumber dana wakaf. Sedangkan kelemahan yang paling tinggi yaitu kurangnya sosialisasi kepada masyarakat. Adapun hasil analisis IFE atau evaluasi faktor internal bahwa peringkat tertinggi dari kekuatan yaitu kemampuan wakaf tunai dalam memperluas basis sumber dana wakaf diikuti dengan kemudahan dan zero cost of fund. Sedangkan kelemahan yang paling terlihat yaitu kurangnya sosialisasi kepada masyarakat diikuti dengan kekurangan SDM nazhir yang profesional.

Hasil evaluasi faktor eksternal (EFE) menunjukkan bahwa peluang tertinggi yaitu potensi wakaf tunai yang tidak terhingga (unlimited) diikuti dengan banyak munculnya lembaga keuangan syariah berikut prodi ekonomi syariah pada perguruan tinggi baik negeri maupun swasta. Sedangkan peringkat tertinggi yang dianggap ancaman yaitu relatif lemahnya political will pemegang otoritas diikuti dengan mayoritas nazhir yang masih tradisional dalam pengelolaan wakaf secara umum.Setelah mengetahui faktorfaktor penting di atas, maka diperoleh strategi pengembangan wakaf tunai di Indonesia 
menggunakan analisis SWOT sebagai berikut: (a) transparansi dan akuntabilitas lembaga wakaf, (b) peningkatan kualitas nazhir pengelola wakaf tunai, (c) strategi pemasaran yang inovatif dari lembaga wakaf dan (e) dukungan regulasi wakaf. Strategi prioritas selanjutnya adalah: (d) pengembangan institusi pendidikan wakaf, dan (g) teknologi dan komputerisasi manajemen wakaf. Yang terakhir namun tidak kalah penting adalah (f) Update dan validasi terkait data wakaf dan wakaf tunai.

Transparansi dan akuntabilitas lembaga wakaf yang termasuk dalam Good Nazhir Governance adalah hal penting dan krusial dalam menjaga trust publik (Ihsan etal (2017), Hasan \& Siraj (2017) dan Masruki \& Shafii (2013)). Demikian pula kualitas nazhir pengelola wakaf yang profesional (Hassan etal, 2018). Tidak kalah penting adalah strategi pemasaran dan pengembangan yang kreatif dan inovatif dari lembaga filantropi semacam lembaga wakaf, menjadi hal penting yang perlu dimiliki (Musa \& Salleh (2018), Saad etal (2016) dan Razak etal (2016)).Sementara itu, beberapa saran yang dapat diberikan penulis antara lain diharapkan adanya komitmen bersama dari berbagai pihak baik dari pembuat kebijakan maupun akademisi dan praktisi dalam menunjang dan mendorong upaya pengembangan industri keuangan syariah khususnya dalam hal ini pengembangan wakaf dan wakaf tunai. Melalui penelitian ini, diharapkan dapat memperluas kajian penelitian akademik terkait wakaf tunai khususnya temuan mengenai strategi-strategi terbaik dalam meningkatkan pengembangan wakaf tunai di Indonesia. Penelitian selanjutnya dapat menggunakan metode yang sama maupun metode lainnya dengan menambah jumlah responden dari pihak-pihak terkait yang dipandang memiliki pemahaman terhadap masalah wakaf tunai di Indonesia.

\section{DAFTAR PUSTAKA}

Alias, N. A. B., Rozali, E. A., \& Sidek, R. S. M. (2015, September). The history of waqf fund development at hospital Fatih, Istanbul (1470-1481M). In Proceedings of The 6th International Symposium on Islam, Civilization and Science (pp. 29-30).

Aziz, M. R. A., Yusof, M. A., Johari, F., Ramli, A., \& Sabri, H. (2014). The relief of higher education loan through Islamic waqf bank. Asian Social Science, 10(22), 175-181.

Budiman, A. A. (2011). Akuntabilitas lembaga pengelola wakaf. Walisongo: Jurnal Penelitian Sosial Keagamaan, 19(1), 75-102.

Cizakca, M. (1998). Awqaf in history and its implications for modern Islamic economies. Islamic Economic Studies, 6(1).

Daud, D., Abdul Rahman, R., \& Sulaiman, Z. (2011). Waqf reporting to fulfil stakeholder attribution in Waqf Islamic Councils. Business Management Quarterly Review, 2(1), 38-53. 
Indonesia, B. (2016). Wakaf: Pengaturan dan Tata Kelola yang Efektif (Seri Ekonomi dan Keuangan Syariah). Department of Islamic Economics and Finance-Bank Indonesia, 40.

Devi, A., \& Rusydiana, A. (2016). Islamic group lending model (GLM) and financial inclusion. International Journal of Islamic Business Ethics, 1(1), 80-94.

Furqon, A. (2011). Analisis praktek perwakafan uang pada lembaga keuangan syariah. Walisongo: Jurnal Penelitian Sosial Keagamaan, 19(1), 157-178.

Harun, F. M., Possumah, B. T., Shafiai, M. H. B. M., \& Nor, A. H. M. (2016). Issues and economic role of waqf in higher education institution: Malaysian experience. AlIqtishad: Jurnal Ilmu Ekonomi Syariah, 8(1), 149-168.

Hasan, R., Siraj, S. A., \& Mohamad, M. H. S. (2017). Antecedents and Outcome of Waqif's Trust in Waqf Institution. Journal of Economic Cooperation \& Development, 38(4), 155-179.

Hilmi, H. (2012). Dinamika pengelolaan wakaf uang: studi sosio-legal perilaku pengelolaan wakaf uang pasca pemberlakuan UU No. 41 tahun 2004 tentang wakaf. Ijtihad: Jurnal Wacana Hukum Islam dan Kemanusiaan, 12(2), 123-143.

Hassan, N., Abdul-Rahman, A., \& Yazid, Z. (2018). Developing a new framework of waqf management. International Journal of Academic Research in Business and Social Sciences, 8(2), 287-305.

Haura, A., \& Baga, L. M. Tanjung.(2016). Wakaf Uang pada Koperasi Jasa Keuangan Syariah (pendekatan Analytical Network Process). Jurnal Al-Muzara'ah.

Ihsan, H., Sulaiman, M. B., Mohammad Alwi, N., \& Adnan, M. (2017). A study of accountability practice in Dompet Dhuafa waqf of Indonesia. Journal of King Abdulaziz University: Islamic Economics, 30(2).

Islahi, A. A. (1992). Provision of public goods: role of the voluntary sector (waqf) in Islamic history. FINANCING DEVELOPMENT.

Mahamood, S. M. (Ed.). (2011). Essential Readings in Contemporary Waqf Issues. CERT Publications.

Masruki, R., \& Shafii, Z. (2013). The development of waqf accounting in enhancing accountability. Middle-East Journal of Scientific Research, 13(13), 1-6.

MAS'UDI, M. O. H. A. M. M. A. D. (2016). Analisis terhadap Pengembangan Wakaf Tunai (Waqf al-Nuqud) di Indonesia. 
Muhammad, A. S. U. (1997). Risalah fi Jawazi Waqf al-Nuqud. Beirut: Dar Ibn Hazm.

Nizar, A. (2014). Faktor-faktor yang Mempengaruhi Persepsi Wakif tentang Wakaf Uang. Esensi: Jurnal Bisnis dan Manajemen, 4(1).

Nurfalah, I., Rusydiana, A. S., Laila, N., \& Cahyono, E. F. (2018). Early warning to banking crises in the dual financial system in Indonesia: The markov switching approach. JKAU: Islamic Economics, 31(2), 133-156.

Keuangan, O. J. (2016). Peran Perbankan Syariah dalam Mengoptimalkan Aset Wakaf Produktif di Indonesia. Jakarta: OJK

Pitchay, A. A., Meera, A. K. M., \& Saleem, M. Y. (2014). Priority of waqf development among malaysian cash waqf donors: An AHP approach. Journal of Islamic Finance, 176(3810), 1-10.

Robbyantono, J. E. (2016). Optimalisasi Kemanfaatan Asset Wakaf Produktif Nasional. In Badan Wakaf Indonesia '3rd Indonesia Islamic Finance Forum'. Jakarta.

Rusydiana, A. (2018). Aplikasi Interpretive structural modeling untuk strategi pengembangan wakaf tunai di Indonesia. Jurnal Ekonomi dan Bisnis Islam (Journal of Islamic Economics and Business), 4(1), 1-17.

Rusydiana, A. S., \& Devi, A. (2018). Elaborating Cash Waqf Development In Indonesia Using Analytic Network. International Journal of Islamic Business and Economics (IJIBEC), 1-13.

Rusydiana, A. S., \& Devi, A. (2018). Analisis pengelolaan dana wakaf uang di Indonesia: Pendekatan metode analytic network process (ANP). Al-Awqaf Jurnal Wakaf dan Ekonomi Islam, 10(1).

Rusydiana, A. S., \& Firmansyah, I. (2018). STRATEGI PENGEMBANGAN LEMBAGA KEUANGAN MIKRO SYARIAH DI INDONESIA: PENDEKATAN MATRIKS IFAS EFAS. Jurnal Ekonomi Islam, 9(1), 46-74.

Rusydiana, A. S., \& Al-Farisi, S. (2016). How far has our Waqf been researched. Jurnal Etikonomi, 15, 1-12.

Shalih. (2007). Peran Wakaf dalam Maqashid Syari'ah. Dissertation at UIN Jakarta, Indonesia. Unpublished.

Abbas, S. (2016). Potensi Harta Wakaf di Indonesia. Pemaparan Kegiatan SILAKNAS MES. 
Rusydiana\&Rahayu | Jurnal Ekonomi dan Bisnis Islam, Vol. 5, No. 1, Januari-Juni 2019

Suhadi. (1995). Pengembangan Tanah Wakaf dalam Rangka Pelaksanaan UndangUndang pokok Agraria di Kabupaten Bantul Yogyakarta. Dissertation at Gajah Mada University, Indonesia. Unpublished.

Suwaidi, A. (2011). WAKAF DAN PENERAPANNYA DI NEGARA-NEGARA MUSLIM. Economic: Journal of Economic and Islamic Law, 1(2), 14-33.

Wadjdy, F., Mursyid, \& Lamtana. (2007). Wakaf \& kesejahteraan umat: filantropi Islam yang hampir terlupakan. Pustaka Pelajar.

Widiastuti, T., Rusydiana, A. S., \& Firmansyah, I. (2017). Development Strategy For Islamic Microfinance Institution In Indonesia: Ifas-Efas Matrix Approach. 